\title{
Effect of Fertilizer Application on Production of Triumfetta Tomentosa Boj.(Fam. Tiliaceae), A Multipurpose Plant in Kenya
}

\author{
Kariuki, S. T. ${ }^{*}$ Kinuthia, N. L. ${ }^{1}$ Mathooko, M. J. ${ }^{1}$ Mucheke, W. ${ }^{2}$ \\ ${ }^{1}$ Egerton University \\ ${ }^{2}$ Kenya Forestry Research Institute
}

\begin{abstract}
Triumfetta tomentosa Boj. is a $\mathbf{n}$ indigenous perennial low shrub found growing naturally in moist habitats. It is commonly found on forest margins and along riparian zones. It is a multipurpose plant exploited by many communities in Kenya as a source of fodder, fiber for making baskets, ropes and hats, while the remaining debarked wood is used for making winnowing trays and firewood. However, as the population increases, more land is being converted into agricultural farms and settlement sites. These development activities coupled with global warming effects due to increasing green house gasses in the atmosphere are threatening the abundance and distribution of this species. The objective of this study was therefore to investigate the effect of fertilizer application on biomass of $T$. tomentosa, if brought under cultivation like any other crop. Seedlings were raised in nurseries from seeds and cuttings at Muguga( Kenya Forest Research Institute-KEFRI). These seedlings were transplanted to the experimental sites in Embu and Meru on eastern slopes of Mt. Kenya. Random Block Design was used at spacing of $30 \mathrm{~cm} \times 30$ $\mathrm{cm}$ and $45 \mathrm{~cm} \times 45 \mathrm{~cm}$ in 3 replicates for each planting material. All plants were harvested after 7 months and above ground biomass was determined in terms of fresh weight in tones/ha. Analysis of variance was used to compare the biomass among different treatments. The results showed significant increase in biomass $(p \leq 0.05)$ of fertilizer application on $T$. triumfetta cultivation. Plants raised from cuttings grew faster than those raised from seeds and had more biomass. This study showed that $T$. tomentosa can be brought under cultivation like any other crop and its productivity can be improved through fertilizer application. This will help in its conservation as it is threatened in the wild.
\end{abstract}

Keywords:- Triumfetta tomentosa Boj. biomass, productivity, fertilizer, conservation.

\section{INTRODUCTION}

Triumfetta tomentosa Boj. is a low shrub that varies in height reaching up to $3 \mathrm{~m}$ with a basal diameter reaching up to $7 \mathrm{~cm}$. The whole plant is covered with pale brown tomentose stellate hairs. The leaves are stipulate, ovate or lanceolate ovate sometimes 3-lobed with acute to subacuminate apex and a cordate to obtuse leaf base and serrate to crenate or dentate margins. The inflorescence is cymose with terminal panicles that have bracteolate florets, the latter bearing capsules that are covered with bristles (Agnew and Agnew, 1994).

This plant grows in wild and is utilized by different communities in Kenya for various products that include fodder, bast fiber for ropes, mats, baskets and hats, while debarked stems are used to make winnowing trays (Gachathi, 2007). However, its biomass in the field is declining rapidly due to deforestation. This is rampant so as to create more land for cultivation in such areas as slopes of Mt. Kenya, Mt. Elgon, Aberdare Ranges, Mau Hills, Cherangany Hills and other moist areas where this species grows naturally. Other threats to the species include overgrazing and the effect of global warming. Since the plant has high economic potential, it is necessary to domestic it by bringing it under cultivation and test, if application of fertilizer has any positive effect on its biomass like other plants under cultivation.

In plant productivity, which is the process of energy input and storage, primary production is crucial involving the transformation of light energy into chemical energy. This results in plant's growth that can be measured in terms of increase in height and girth or in biomass. This biomass is the Net Primary Production that accumulates over time. Some of this accumulation is turned over seasonally through decomposition, while some of it is retained over a longer period as living matter which in a given area gives the standing crop biomass expressed as weight per unit of area. This can be above ground biomass if dealing with shoot system alone, below ground biomass if dealing with root system alone or total biomass if it involves both systems. It is known that the nutrition of the plant is one of the most important factors to control agricultural productivity and quality. Rates of nutrients in the soil affects the quality of yield and application of fertilizers is a priority in agricultural production (Liu, et al; 2014). Fertilizer application is required in order to replace crop land nutrients that have been consumed by previous plant growth with ultimate goal of maximizing productivity and economic returns (Rai et al;2014).

Since the beginning of plant cultivation or origin of agriculture crops are found to respond positively to the application of both organic and inorganic fertilizers (Dubey, et al; 2012). Work done by Liu, et al; 2011, showed that organic manure promoted root activity in 40 days after transplanting Stevia rabaudiana Bertoni compared with chemical fertilizer, and dry weight of above 
ground exceeded that of chemical fertilizer in 60 days. This root activity is believed to enhance photosynthetic activity in later growth stages resulting in increased biomass (ICESD,2012).

From various studies it is noted that plant growth is influenced by temporal and spatial effect, plant densities, intercropping and mixed cropping, water supply, mineral supply and green house effect(Ortega et al;2016). In Kenya temporal effect depends on whether the plant is propagated during long rains or short rains with long rains having a greater effect on many plants. Spatial usually affects plant densities giving plant population in a given unit of land and has been noted that yield per plant decreases as the number of plants increase per unit of land (Islam et al; 2017).

\section{MATERIALS AND METHODS}

\section{The study area}

This study was carried out on the eastern slopes of Mt. Kenya which was purposely selected on the grounds that it was once abundantly covered with Triumfetta tomentosa plant species. This area lies at an average altitude of 2194 $\mathrm{m}$. The area has a mean annual average temperature ranging from $25^{\circ} \mathrm{C}$ to $27^{\circ} \mathrm{C}$ and the rainfall is bimodal with two peaks March to May (Long Rains) and October to December (Short Rains) with an annual average ranging from $600 \mathrm{~mm}$ to $1000 \mathrm{~mm}$. Geologically the region consists of tertially recent volcanic rocks with Ando-like soils. In areas that have been cultivated for a long time there are Ferralsols which are reddish or yellowish and very uniform tropical clay soils. These have a uniform soil profile some metres thick, well drained and with good permeability and stable structure. Such portions are exhausted of bases and therefore less fertile. The region is cleared of natural vegetation for cultivation and settlements.

\section{$>$ Propagation of T.tomentosa from cuttings}

The cuttings were collected from Mt. Kenya Forest. They were treated with rooting hormone Rhizopon AA $1 \%$ (IBA). Potting was done using $15 \mathrm{~cm} \times 10 \mathrm{~cm}$ punched polythene papers. Before planting the tubes were also treated with Milraz a fungicide to control fungi and sterilized forest soil was used. The cuttings were covered with polythene sheets and were watered every 2 weeks until they were ready for transplantation into the field after reaching about $25-40 \mathrm{~cm}$.

\section{Propagation of T. tomentosa from seeds}

Seeds were collected from Mt. Kenya Forest, dried in the laboratory and finally broadcast on seed beds. They were watered until they reached $5 \mathrm{~cm}$ after germination. They were then pricked and were watered for four months until they were about $20-40 \mathrm{~cm}$ after which they were transplanted.

\section{Transplantation of seedlings into the field}

The seedlings were classified as those from cuttings (Cs) and those from seeds (Ss). Then those for spacing 30 $\mathrm{cm} \times 30 \mathrm{~cm}$ as ( $\mathrm{C} 1$ and $\mathrm{S} 1$ ), while those for spacing $45 \mathrm{~cm}$ $\mathrm{x} 45 \mathrm{~cm}$ as (C2 and S2 ). They were then planted in triplicates using Random Block Design in plots of $3 \mathrm{~m} \times 3$ $\mathrm{m}$ during the Long Rains in holes of $10 \mathrm{~cm} \times 10 \mathrm{~cm}$. The treatments were with fertilizer (NPK) or without.

\section{Determination of biomass of T. tomentosa}

The plants were harvested by cutting the stem at the base using a sharp panga ( machete). The harvested plant materials per treatment were put in gunny bags including stem, twigs, leaves and flowers and weighed immediately in the field under shade using spring balance. The weight was recorded in kilograms and later calculated as tones per hectare.

\section{RESULTS AND DISCUSSIONS}

The biomass per site and treatment were recorded as follows:

\begin{tabular}{|c|c|c|c|}
\hline Site & Spacing & Treatment & Biomass $\mathrm{t} / \mathrm{ha}$ \\
\hline \multirow[t]{8}{*}{ Embu } & $30 \mathrm{~cm} \times 30 \mathrm{~cm}$ & $\mathrm{C} 1$ & 34.08 \\
\hline & & $\mathrm{C} 2$ & 11.01 \\
\hline & & $\mathrm{S} 1$ & 39.92 \\
\hline & & $\mathrm{S} 2$ & 9.45 \\
\hline & $45 \mathrm{~cm} \mathrm{x} 45 \mathrm{~cm}$ & $\mathrm{C} 1$ & 43.63 \\
\hline & & $\mathrm{C} 2$ & 8.44 \\
\hline & & $\mathrm{S} 1$ & 81.05 \\
\hline & & $\mathrm{S} 2$ & 12.46 \\
\hline \multirow[t]{8}{*}{ Meru } & $30 \mathrm{~cm} \times 30 \mathrm{~cm}$ & $\mathrm{C} 1$ & 15.67 \\
\hline & & $\mathrm{C} 2$ & 3.86 \\
\hline & & $\mathrm{S} 1$ & 24.43 \\
\hline & & $\mathrm{S} 2$ & 3.18 \\
\hline & $45 \mathrm{~cm} \mathrm{x} 45 \mathrm{~cm}$ & $\mathrm{C} 1$ & 33.55 \\
\hline & & $\mathrm{C} 2$ & 5.30 \\
\hline & & $\mathrm{S} 1$ & 51.05 \\
\hline & & $\mathrm{S} 2$ & 22.38 \\
\hline
\end{tabular}


Analysis of variance for fertilizer application

\begin{tabular}{|c|c|c|c|c|c|}
\hline Source of variation & d.f. & s.s. & m.s. & v.r. & F pr. \\
\hline Fertilizer level & 1 & 27233 & 27233 & 22.09 & \\
\hline Treatment & & & & & \\
\hline Residual & 5389 & 6644032 & 1233 & & \\
\hline Total & 5390 & 6671266 & & & \\
\hline
\end{tabular}

Table 2

Analysis of variance for the spacing

\begin{tabular}{|c|c|c|c|c|c|}
\hline Source of variation & d.f. & s.s. & m.s. & v.r. & F pr. \\
\hline Fertilizer level & 1 & 21647 & 21647 & 17.88 & $<.05$ \\
\hline Treatment & 3 & 122307 & 40769 & 33.67 & \\
\hline Residual & 5385 & 6520642 & 1211 & & \\
\hline Total & 5389 & 6669987 & & & \\
\hline
\end{tabular}

Table 3

The results show that there was a significant difference in terms of biomass between the plants spaced at $30 \mathrm{~cm} \times 30 \mathrm{~cm}$ and those spaced at $45 \mathrm{~cm} \times 45 \mathrm{~cm} \mathrm{p}<0.05$. This was also the case with biomass between plants supplied with fertilizers and control. According to Islam etal; 2017, spatial distribution or spacing of plants is crucial in determining their productivity. Closely planted plants give a higher density of plants per unit of land. This results in a more competition of resources such as light, water and mineral salts required for primary productivity. This gives low weight per plant and total weight per unit of land. It is reported by Liu et al; 2011 that fertilizers promote root activity enhancing photosynthesis. This fertilizer application is one of the simple technologies applied by many farmers (Liu, etal; 2011). This increase of yield or biomass per unit of land in agriculture due to application of fertilizers contributes to success of Green Revolution (Afolabi et al; 2013).

\section{CONCLUSION}

From this study, it was concluded that application of fertilizer in Triumfetta tomentosa cultivation is necessary as it increases biomass just like other crops. Also propagation from cuttings results in faster growth and higher biomass than from the seeds.

\section{RECOMMENDATIONS}

We recommend in-situ and ex-situ conservation of Triumfetta tomentosa as it is a multipurpose species whose values are yet to be evaluated. Its leaf nutritive values need to be known, if it is to be used as fodder and mechanical fiber extraction to be tested as so far only manual methods are used.

\section{ACKNOWLEDGEMENTS}

We are grateful to NACOSTI for funding this study and also Egerton Universityand KEFRI for facilitating the experimental component.

\section{REFERENCES}

[1]. Afolabi, M. T., Adeboye, O. B. and Awogbuyi, O. T. (2013). Environmental Effect of Application of Fertilizers and Pesticides on Water and Soil in Ibadan, Nigeria. JETEAS 4(6) 773-777.

[2]. Agnew, A. D. Q. and Agnew. S. (1994). A Flora of the Ferns and Herbaceous Flowering Plants of Upland Kenya. East Africa Natural History Society.Upland Kenya Wild Flowers.

[3]. Dubey, V., Patel, A. K., Shikla, S. S. and Singh(2012). Impact of Continuous Use of Fertilizers . Int. J. Eng.Res.\& Dev. Vol.3(11) 13-16

[4]. Gachathi, M. (2007). A Guide to Plant Names, Uses and Cultural Values. Kikuyu Botanical Dictionary. Tropical Botany, Gituamba, Kenya.

[5]. ICESD, (2012). Investigation of Effects of Chemical Fertilizers on Environment. Procedia APcBEE, Hong Kong.

[6]. Islam, A., Ferdous G., Akter, A., Hossain, A. and Nandnani, D. (2017). Agriculture: Effect of Organic, Inorganic and Plant Spacing on the Growth and Yield of Cabbage. Baglandesh Agr. Univ. Baglandesh.

[7]. Liu, W., Sung, Y., Chen, C. and Lai, Y. (2014). Effects of Nitrogen Fertilizers on the Growth and Nitrate Content of Lettuce ( Lactuca sativa L.). Int. J. Environ. Res. Public Health 2014(11)4427-4440.

[8]. Liu, X., Ren, G., Shi, Y. (2011). The Effect of Organic Manure and Chemical Fertilizer on Growth and Development on Stevia rebaudiana. Qingdao, China.

[9]. Ortega, R., Miralles, I., Erik Meca, D., Gazquez, C. J. and Domene, M. A (2016). Effect of Organic and Synthetic Fertilizers on the Crop Yield and Macronutrients in Soil. Soil Analysis and Plant analysis, Vol. 47(10) 1216-1226.

[10]. Rai, N., Ashya P.and Rathore, M. L. (2014). Comparative Study of the Effect of Chemical Fertilizers and Organic Fertilizers on Eisenia foetida. International Journal of Research in Science, Engineering and Technology. 